\title{
Penerapan Model Pembelajaran STM untuk Meningkatkan Keterampilan Berpikir Kreatif dan Rasa Ingin Tahu Siswa Kelas IV SD Negeri Pesanggrahan 02
}

\author{
Cholis Makhvudah $^{1 \bowtie}$, Karma Iswasta Eka ${ }^{2}$ Dhi Bramasta $^{3}$
}

Program Studi PGSD, Universitas Muhammadiyah Purwokerto, Indonesia

$\bowtie$ E-mail: cholis.makhvu28@gmail.com

\begin{abstract}
Abstrak
Penelitian ini bertujuan untuk meningkatkan keterampilan berpikir kreatif dan rasa ingin tahu siswa melalui model pembelajaran Sains Teknologi Masyarakat (STM) pada tema 8 Daerah Tempat Tinggalku di kelas IV SD Negeri Pesanggrahan 02. Jenis penelitian ini adalah penelitian tindakan kelas model Kemmis dan MC Taggart yang dilaksanakan dalam satu siklus. Penelitian ini dilaksanakan pada semester II tahun ajaran 2019/2020 pada bulan Maret. Subjek yang digunakan siswa kelas IV SD Negeri Pesanggrahan 02 yang berjumlah 22 siswa yang terdiri dari 17 siswa lakilaki dan 5 siswa perempuan. Alat pengumpulan data menggunakan lembar evaluasi keterampilan berpikir kreatif, lembar observasi aktivitas guru, lembar observasi aktivitas siswa, lembar observasi rasa ingin tahu dan lembar angket sikap rasa ingin tahu siswa. Hasil penelitian menunjukkan adanya keterampilan berpikir kreatif pada siswa dari lembar tes keterampilan berpikir kreatif pada siklus I yaitu 69,32\% dengan kriteria baik. Hasil lembar evaluasi sikap rasa ingin tahu siswa dari nilai rata-rata siswa pada siklus I yaitu 59,66\% dengan kriteria cukup baik. Kesimpulan bahwa melalui model pembelajaran Sains Teknologi Masyarakat (STM ) menunjukan adanya peningkatan keterampilan berpikir kreatif dan rasa ingin tahu siswa pada tema 8 Daerah Tempat Tinggalku di kelas IV SD Negeri Pesanggrahan 02.
\end{abstract}

Kata Kunci: Keterampilan Berpikir Kreatif; Rasa Ingin Tahu; Model Pembelajaran Sains Teknologi Masyarakat (STM).

\begin{abstract}
This study aims to improve creative thinking skills and students curiosity through the Science, Technology, and Society (STS) learning models on the theme 8 Daerah Tempat Tinggalku in class IV SD Negeri Pesanggrahan 02. This type of research is classroom action research Kemmis and MC Taggart models conducted in one cycle. This research was conducted in the second semester of the 2019/2020 school year in March. The subjects in this study were students in class IV SD Negeri Pesanggrahan 02, totaling 22 students consisting of 17 male students and 5 female students. Data collection tools in this study used an evaluation sheet of creative thinking skills, a teacher activity observation sheet, a student activity observation sheet, a curiosity observation sheet, and a student curious attitude questionnaire sheet. The results showed the existence of creative thinking skills in students from the creative thinking skills test sheet in the first cycle that is $69.32 \%$ with good criteria. The results of the evaluation sheet of students curiosity attitudes from the average value of students in the first cycle were 59.66\% with quite good criteria. The conclusion that through of the Science, Technology, and Society (STS) learning model there is an increase in students' creative thinking skills and curiosity on the theme 8 Daerah Tempat Tinggalku in grade IV of SD Negeri Pesanggrahan 02.
\end{abstract}

Keywords: Creative Thinking Skills; Curiosity; Science Learning Model, Technology, and Society (STS). 


\section{PENDAHULUAN}

Pendidikan merupakan proses interaksi antara guru dan siswa yang mendorong terjadinya proses pembelajaran. Guru bertugas membuat sumber daya manusia menjadi cakap dan berkualitas. Pendidikan menurut Undang-Undang Nomor 20 Tahun 2001 tentang Sistem Pendidikan Nasional Bab 1 Pasal 1, merupakan usaha sadar dan terencana untuk mewujudkan suasana belajar dan proses pembelajaran agar peserta didik secara aktif mengembangkan potensi dirinya untuk memiliki kekuatan spiritual keagamaan, pengendalian diri, kepribadian, kecerdasan, akhlak mulia, serta keterampilan yang diperlukan dirinya, masyarakat, bangsa dan negara.

Proses belajar mengajar merupakan bagian penting dalam lembaga formal, karena keberhasilan proses belajar mengajar ditentukan oleh proses belajar mengajar berlangsung. Proses belajar yang menarik juga akan menjadikan siswa lebih aktif, interaktif, dan komunikatif. Pendidikan diharapkan mampu membentuk karakter yang menjadikan manusia lebih baik melalui proses pembelajaran. Maju mundurnya suatu bangsa menurut Sunito (Maskanah dan Wicaksono, 2019: 467) ditentukan oleh kreativitas pendidikan bangsa itu sendiri dan kompleksnya masalah kehidupan menuntut Sumber Daya Manusia (SDM) yang handal dan mampu berkompetensi.

Di era globalisasi ini dunia terus mengalami perubahan. Ilmu pengetahuan dan teknologi juga berkembang sangat cepat, agar mampu berperan secara bermakna di era globalisasi ini, maka diperlukan keterampilan hidup yang lebih sesuai dengan tuntutan perkembangan zaman. Beberapa puluh tahun sebelumnya dianggap cukup dengan kemampuan dasar dalam membaca, menulis, dan berhitung, maka pada abad ke-21 ini diperlukan ketrampilan lain agar dapat hidup fungsional dan bermakna. Kecakapan abad-21 menurut Greenstein (Maskanah dan Wicaksono, 2019: 467) mencakup kemampuan berpikir tingkat tinggi (high order thinking skills), komunikasi dan kolaborasi. Salah satu kompoen dari High Order Thinking Skills yaitu kemampuan berpikir kreatif. Menyikapi tantangan pendidikan diabad-21, siswa dituntut mampu menyelesaikan masalah dalam kehidupan sehari-hari melalui sains atau ilmu pengetahuan yang diperolehnya, untuk itulah paradigma pembelajaran di kelas perlu diubah dari teacher centered ke arah student centered (berpusat pada siswa) yaitu dengan diterapkannya kurikulum 2013 di Indonesia.

Keterampilan berpikir kreatif menurut Nurlaela dan Ismayanti (2015: 6) merupakan suatu kegiatan mental yang digunakan seorang untuk membangun ide atau gagasan yang baru. Berpikir kreatif mengabaikan hubunganhubungan yang sudah mapan, dan menciptakan hubungan-hubungan tersendiri. Berpikir kreatif menurut Munandar (Arini dan Asmila, 2017: 26) yang sering disebut juga berpikir divergen ialah memberikan macammacam kemungkinan jawaban berdasarkan informasi yang diberikan dengan penekanan pada keragaman jumlah dan kesesuain. Adapun, indikator berpikir kreatif menurut Munandar (Arini dan Asmila, 2017: 27) yang merupakan cara memupuk sikap mengambil sebagai berikut; 1) Berpikir lancar (fluency), 2) Berpikir luwes (fleksibel), 3) Berpikir orisinil, dan 4) Berpikir terperinci (elaborasi). Keterampilan berpikir kreatif adalah kemampuan yang muncul karena adanya potensi sehingga perlu dilatih karena membuat lancar dan luwes (fleksibel) dalam berpikir, mampu melihat suatu masalah dari berbagai sudut pandang, dan mampu melahirkan banyak gagasan. Gagasan tersebut menjelaskan kegiatan belajar tidak hanya fokus pada bidang 
akademik saja, tetapi dituntut kemampuan untuk menganalisis permasalahan dan tidak ditekankan pada hafalan, sementara menurut Winarsih (2012: 43) pendidikan selama ini masih menekankan pada hafalan. Hafalan yang banyak membuat siswa dituntut mampu memahami teori dengan hafalannya bukan pemahamannya yang berdampak pada kurangnya keterampilan berpikir kreatif siswa dan rasa ingin tahu siswa. Kurangnya berpikir kreatif siswa dan rasa ingin tahu siswa ditandai dengan kesulitan dalam menyusun kalimat, tidak memberikan gagasan dengan gaya bahasa sendiri, dan tidak menggabungkan gagasan sendiri dengan gagasan orang lain.

Hasil observasi di kelas IV SD Negeri Pesanggrahan 02, menunjukan bahwa dalam proses pembelajaran masih adanya siswa yang tidak bertanya mengenai materi yang telah disampaikan oleh guru saat proses pembelajaran berlangsung. Lebih lanjut, siswa juga tidak bisa menjawab pertanyaan yang diberikan oleh guru berkaitan dengan materi pembelajaran, ketika diberikan pertanyaan siswa hanya merangkumnya saja namun tidak berusaha mencari jawaban dalam bacaan dan mencari materi terkait dengan yang ditanyakan oleh guru dibuku paket maupun menyebutkan atau mengaitkan contoh permasalahan yang pernah di alami atau yang terjadi di masyarakat. Hal tersebut menunjukan kurangnya berpikir kreatif dan rasa ingin tahu pada siswa terhadap materi pelajaran yang diajarkan oleh guru. Proses belajar mengajar yang dilakukan oleh guru sudah cukup baik, namun perlu dioptimalkan dalam variasi memilih, menggunakan serta memanfaatkan strategi, metode, model dan alat peraga.

Penerapan model, maupun strategi pembelajaran yang bervariasi dan menarik, dapat meningkatkan berpikir kreatif dan rasa ingin tahu pada siswa. Guru sebagai fasilitator dituntut untuk lebih kreatif, baik menggunakan strategi, model dan alat peraga yang memadai dalam proses pembelajaran. Diperlukan upaya untuk meningkatkan keterampilan berpikir kreatif dan rasa ingin tahu siswa yaitu dengan memperbaiki kualitas pembelajaran agar lebih bermakna.

Pembelajaran yang bermakna diperoleh ketika siswa menemukan dan memahami konsep melalui pengalamannya sendiri. Pengalaman tersebut dapat diperoleh melalui eksperimen atau percobaan. Guru mengatakan saat pembelajaran berlangsung siswa tidak melakukan percobaan. Hal itu menunjukan bahwa psikomotor siswa masih rendah. Siswa tidak diajak untuk mengamati suatu benda atau keadaan di sekitar sehingga kurang memahami apa isi pembelajaran.

Salah satu upaya memperbaiki kualitas pembelajaran yaitu dengan penerapan model pembelajaran yang dapat mendorong siswa agar keterampilan berpikir kreatif dan rasa ingin tahu dapat meningkat. Banyak model pembelajaran yang dapat digunakan untuk meningkatkan keterampilan berpikir kreatif dan rasa ingin tahu siswa salah satunya adalah model pembelajaran Sains Teknologi Masyarakat (STM).

Pendidikan sains dengan STM menurut Hunaepi, dkk (2014: 53) berpendapat menjadikan siswa sebagai pemeran aktif dalam pelajaran sains itu sendiri karena melalui program STM akan mempertinggi aspek kreativitas siswa. Siswa lebih banyak memiliki gagasan yang orisinil, penjelasan-penjelasan serta evaluasi atas dirinya. Siswa mampu menyelesaikan permasalahan yang dihadapkan kepadanya dalam bentuk dan situasi yang lain. Adapun ranah yang terlibat dalam model pembelajaran STM menurut Poedjiadi (2010: 131) yaitu konsep, fakta dan generalisasi, proses, kreativitas, aplikasi konsep, sikap dan tindakan nyata. 
Uraian di atas menjadi pertimbangan peneliti berkolaborasi bersama guru melakukan penelitian yang memfokuskan pada peningkatan keterampilan berpikir kreatif dan rasa ingin tahu pada siswa. Inovasi dalam penelitian ini adalah dalam pembelajaran berlangsung tidak hanya di dalam kelas saja, namun juga dilakukan di luar kelas untuk mencari, menemukan dan mempelajari teknologi sederhana yang ada di masyarakat yang dikaitkan dengan materi pelajaran. Materi pelajaran yang akan dilakukan salah satunya adalah gaya dengan gerak pada pada peristiwa yang dipraktekan siswa secara langsung.

\section{METODE PENELITIAN}

Jenis penelitian ini adalah penelitian tindakan kelas (PTK). Penelitian Tindakan Kelas (PTK) merupakan pencermatan atau pengamatan yang dilakukan dengan sengaja terhadap kegiatan belajar mengajar yang terjadi di kelas antara guru dan siswa secara bersamaan, yang bertujuan untuk memperbaiki dan meningkatkan kualitas pembelajaran.

PTK ini dilakukan di kelas IV SDN Pesanggrahan 02 terletak di desa Pesanggrahan, Kecamatan Kesugihan, Kabupaten Cilacap. Subyek penelitian ini merupakan siswa kelas IV berjumlah 22 siswa, yang terdiri dari 17 siswa laki-laki dan 5 siswa perempuan. Desain penelitian yang digunakan adalah model Kemmis dan Mc. Taggart terdiri dari empat tahapan penelitian yaitu tahap perencanaan (planning), tindakan (action), observasi (observation), dan refleksi (reflection).

Instrumen yang digunakan adalah lembar observasi kegiatan aktivitas guru, lembar observasi kegiatan aktivtias peserta didik, lembar observasi sikap rasa ingin tahu, angket sikap rasa ingin tahu pada siswa, kisi-kisi soal kemampuan berpikir kreatif dan lembar tes kemampuan berpikir kreatif. Teknik pengumpulan data yaitu melalui teknik tes dan teknik non tes. Teknik tes menggunakan soal uraian yang diberikan pada siswa sedangkan teknik non tes berupa obervasi dan dokumentasi saat penelitian. Analisis data yang digunakan pada penelitian untuk mendapatkan data yang diperoleh, baik data penelitian melalui teknik tes atau non tes. Analisis data yang diperoleh meliputi analisis kemampuan berpikir kreatif pada siswa, analisis angket sikap rasa ingin tahu pada siswa, analisis lembar observasi sikap rasa ingin tahu pada siswa, analisis lembar observasi kegiatan aktivitas guru dan lembar observasi kegiatan aktivtitas siswa

\section{HASIL DAN PEMBAHASAN \\ Hasil Kemampuan berpikir kreatif Siswa Siklus I}

Selama proses pembelajaran menggunakan model pembelajaran STM pada Tema 8 "Daerah Tempat Tinggalku" di kelas IV SDN Pesanggrahan 02 dilakukan tes uraian kemampuan berpikir kreatif berjumlah 5 soal dari 4 indikator, pada setiap pertemuan di siklus I. Berikut rekapitulasi hasil tes kemampuan berpikir kreatif siklus I dapat dilihat pada Tabel 1 .

Tabel 1. Rekapitulasi Hasil

KemampuanBerpikir Kreatif

\begin{tabular}{|c|c|c|c|c|c|}
\hline \multirow{2}{*}{\multicolumn{2}{|c|}{$\begin{array}{c} \\
\text { Indikator } \\
\text { Kemampuan } \\
\text { Berpikir Kreatif }\end{array}$}} & \multicolumn{2}{|c|}{ Skor } & \multirow[b]{2}{*}{$J m l$} & \multirow[b]{2}{*}{ Rata-Rata } \\
\hline & & $P 1$ & $P 2$ & & \\
\hline 1. & $\begin{array}{l}\text { Berpikir lancar } \\
\text { (fluency). }\end{array}$ & 1,36 & 2,14 & $3,5 z$ & 1,75 \\
\hline \multirow{3}{*}{$\begin{array}{l}2 . \\
3 . \\
4 .\end{array}$} & $\begin{array}{l}\text { Berpikir luwes } \\
\text { (fleksibel). }\end{array}$ & 1,88 & 1,98 & 3,86 & 1,93 \\
\hline & Berpikir orisinil. & 2 & 2,45 & 4,45 & 2,26 \\
\hline & $\begin{array}{l}\text { Berpikir } \\
\text { terperinci } \\
\text { (elaborasi). }\end{array}$ & 2,18 & 2,64 & 4,82 & 2,41 \\
\hline \multicolumn{2}{|c|}{ JUMLAH } & 7,42 & 9,21 & & 16,63 \\
\hline \multicolumn{2}{|c|}{ RATA-RATA } & 1,86 & 2,30 & & 2,08 \\
\hline \multicolumn{2}{|c|}{ KRITERIA } & Baik & Baik & & Baik \\
\hline
\end{tabular}


Tabel 1 menunjukkan bahwa siklus I pertemuan 1 siswa mendapatkan rata-rata 1,86 dengan kriteria baik hal ini tentu belum mencapai indikator keberhasilan penelitian. Sedangkan pada siklus I pertemuan 2 mendapatkan skor rata-rata 2,30 dengan kriteria baik. Rata-rata siklus I dari pertemuan 1 dan pertemuan 2 memperoleh skor rata-rata 2,08 dengan menunjukan kriteria baik. Pada siklus I setiap pertemuan menunjukan adanya peningkatan setiap indikator, dibuktikan dengan indiaktor 1 mengalami peningkatan yaitu 0,78 . Indikator 2 mengalami peningkatan skor 0,10 . Indikator 3 mengalami peningkatan skor 0,45 . Indikator 4 mengalami peningkatan skor sebesar 0,46. Pencapain dari hasil siklus 1 dari pertemuan 1 dan pertemuan 2 mencapai indikator keberhasilan. Indikator keberhasilan pada penelitian ini yaitu mencapai skor 1,8 s/d 2,4 dengan kriteria baik.

\section{Hasil Sikap Rasa Ingin Tahu pada Siswa}

Selama proses pembelajaran menggunakan model pembelajaran pada Tema 8 "Daerah Tempat Tinggalku" di kelas IV SDN Pesanggrahan 02 dilakukan penilaian lembar observasi rasa ingin tahu siswa berjumlah 4 indikator pada setiap pertemuan di siklus I.

hasil rekapitulasi observasi sikap rasa ingin tahu pada siswa, pertemuan 1 siswa mendapatkan rata-rata 51,14\% mendapatkan kriteria cukup baik, tentunya hal ini mencapai belum indikator keberhasilan, sedangkan pertemuan 2 mengalami peningkatan mendapatkan ratarata $68,18 \%$ dengan kriteria baik. Rata-rata dari pertemuan 1 dan pertemuan 2 memperoleh nilai rata-rata $59,66 \%$ dengan menunjukan kriteria cukup baik, pencapain dari siklus I dari pertemuan 1 dan pertemuan 2 belum keberhasilan.
Berikut rekapitulasi hasil angket rasa ingin tahu pada siswa siklus I dapat dilihat pada tabel 2, yaitu:

Tabel 2. Rekapitulasi Hasil Observasi Sikap Rasa Ingin Tahu Siswa

\begin{tabular}{|c|c|c|c|c|c|}
\hline \multirow[b]{2}{*}{ No } & \multirow{2}{*}{$\begin{array}{c}\text { Aspek Sikap } \\
\text { Rasa Ingin } \\
\text { Tahu Siswa }\end{array}$} & \multicolumn{2}{|c|}{ SKOR } & \multirow[b]{2}{*}{$J m l$} & \multirow{2}{*}{$\begin{array}{l}\text { Rata- } \\
\text { Rata }\end{array}$} \\
\hline & & P1 & P2 & & \\
\hline 1. & $\begin{array}{l}\text { Penerapan } \\
\text { eksplorasi dan } \\
\text { elaborasi dalam } \\
\text { pembelajaran. }\end{array}$ & 6 & 13 & 19 & 9,5 \\
\hline 2. & $\begin{array}{l}\text { Memanfaatkan } \\
\text { media } \\
\text { pembelajaran } \\
\text { (cetak dan } \\
\text { elektronik) yang } \\
\text { menumbuhkan } \\
\text { keingintahuan. }\end{array}$ & 19 & 20 & 39 & 19,5 \\
\hline 3. & $\begin{array}{l}\text { Menumbuhkan } \\
\text { keinginan untuk } \\
\text { melakukan } \\
\text { penelitian. }\end{array}$ & 12 & 18 & 30 & 15 \\
\hline 4. & $\begin{array}{l}\text { Berwawasan } \\
\text { yang luas. }\end{array}$ & 8 & 9 & 17 & 8,5 \\
\hline $\mathbf{J U}$ & ILAH & 45 & 60 & & \\
\hline $\begin{array}{l}\text { RA } \\
\text { KR }\end{array}$ & $\begin{array}{l}\text { A-RATA } \\
\text { TERIA }\end{array}$ & $\begin{array}{c}51,14 \% \\
\text { Cukup } \\
\text { Baik }\end{array}$ & $\begin{array}{c}68,18 \% \\
\text { Baik }\end{array}$ & $\begin{array}{r}59, \\
\mathrm{Cu} \\
\mathrm{B}\end{array}$ & $\begin{array}{l}6 \% \\
\text { xup } \\
\text { ik }\end{array}$ \\
\hline
\end{tabular}

Temuan pada siklus I menunjukan adanya peningkatan indikator. Pada indikator 1 menunjukan peningkatan yaitu 7. Indikator 2 menunjukan peningkatan yaitu 1 . Indikator 3 mengalami penuruan dari pertemuan 1 ke pertemuan 2 yaitu sebesar 6 . Indikator 4 menunjukan penurunan dari pertemuan 1 ke pertemuan 2 yaitu sebesar 1. Pada siklus I belum mencapai indikator keberhasilan dengan kriteria baik.

\section{Pembahasan}

Pada Penelitian Tindakan Kelas (PTK) di kelas untuk meningkatkan kemampuan berpikir kreatif dilakukan tes disesuaikan dengan indikator kemampuan berpikir kreatif dan meningkatkan sikap rasa ingin tahu pada siswa dilakukan lembar observasi dan angket rasa ingin tahu siswa sesuaikan dengan indicator sikap rasa ingin tahu pada siswa. Indikator berpikir kreatif menurut Munandar (Arini dan Asmila, 2017: 27) yaitu 1) Berpikir lancar (fluency), 2) Berpikir luwes (fleksibel), 
3) Berpikir orisinil, 4) Berpikir terperinci (elaborasi). Hasil skor rata-rata kemampuan berpikir kreatif setiap indikator siklus I pada pertemuan 1 dan 2, dapat dilihat pada gambar 1 sebagai berikut:

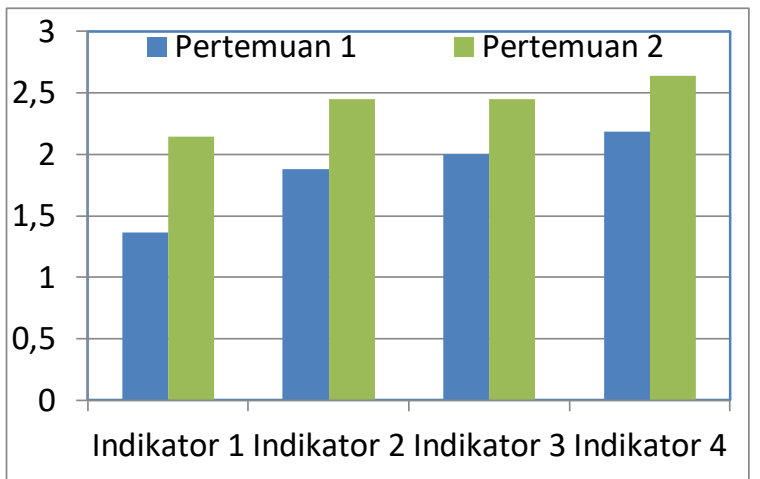

Gambar 1. Hasil Tes Kemampuan Berpikir Kreatif Tiap Indikator pada Siklus I

Temuan dalam penelitian ini ditunjukkan dengan peningkatan hasil tes kemampuan berpikir kreatif setiap indikator berpikir kreatif, yaitu indikator 1) Berpikir lancar (fluency), pada siklus I pertemuan 1 siswa memperoleh skor rata-rata 1,36 kriteria cukup baik sedangkan siklus I pertemuan 2 memperoleh skor rata-rata 2,14 kriteria baik. Indikator 2) Berpikir luwes (fleksibel), pada siklus I siswa memperoleh skor rata-rata 1,88 kriteria baik, sedangkan siklus I pertemuan 2 memperoleh skor rata-rata 1,98 dengan kriteria baik. Indikator 3) Berpikir orisinil, pada siklus I pertemuan 1 siswa memperoleh skor rata-rata 2 dengan kriteria baik sedangkan siklus I pertemuan 2 memperoleh skor rata-rata 2,45 dengan kriteria sangat baik. Indikator 4) Berpikir terperinci (elaborasi), pada siklus I pertemuan 1 siswa memperoleh skor ratarata 2,18 dengan kriteria baik sedangkan siklus I pertemuan 2 memperoleh skor ratarata 2,64 dengan kriteria sangat baik. Penelitian ini yang dilakkan selama 1 siklus yang terdiri dari 2 pertemuan berhasil mencapai indikator keberhasilan dengan kemampuan berpikir kreatif siswa mencapai kriteria baik.

Indikator rasa ingin tahu pada siswa Menurut Sutarna (2018: 11) indikator pencapaian pembelajaran sebagai berikut; 1) penerapan eksplorasi dan elaborasi dalam pembelajaran, 2) memanfaatkan media pembelajaran (cetak dan elektronik) yang menumbuhkan keingintahuan, 3) menumbuhkan keinginan untuk melakukan penelitian, dan 4) berwawasan yang luas. Berikut gambar 2 hasil skor nilai sikap rasa ingin tahu pada siswa setiap indikator siklus I pada pertemuan 1 dan 2, yaitu:

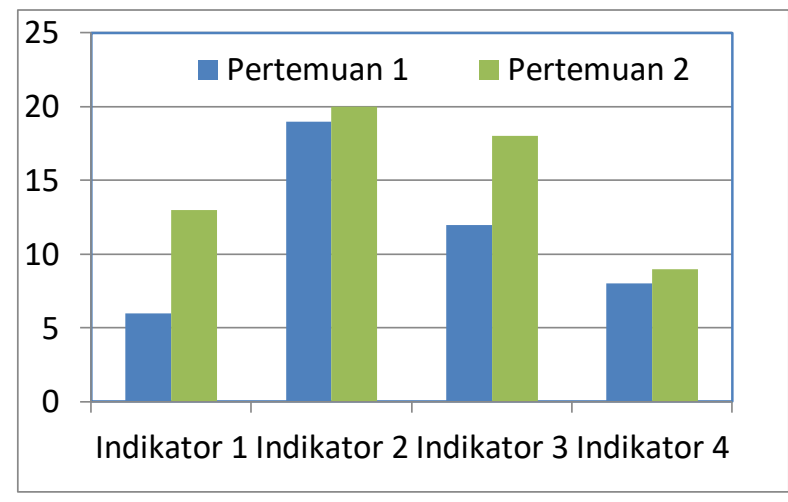

Gambar 2. Hasil Observasi Sikap Rasa Ingin Tahu Tiap Indikator pada Siklus I

Temuan dalam penelitian ini ditunjukkan dengan peningkatan hasil observasi sikap rasa ingin tahu pada siswa dengan setiap indikatornya, yaitu indikator ; 1) penerapan eksplorasi dan elaborasi dalam pembelajaran, luas pada siklus I pertemuan 1 siswa memperoleh skor nilai 6 dengan kriteria kurang baik sedangkan siklus I pertemuan 2 memperoleh skor nilai 13 dengan kriteria cukup baik, 2) memanfaatkan media pembelajaran (cetak dan elektronik) yang menumbuhkan keingintahuan, luas pada siklus I pertemuan 1 siswa memperoleh skor nilai 19 dengan kriteria baik sekali sedangkan siklus I pertemuan 2 memperoleh skor nilai 20 dengan kriteria baik sekali, 3) menumbuhkan keinginan untuk melakukan penelitian, luas pada siklus I pertemuan 1 siswa memperoleh 
skor nilai 12 dengan kriteria cukup baik sedangkan siklus I pertemuan 2 memperoleh skor nilai 18 dengan kriteria baik sekali, dan 4) berwawasan yang luas pada siklus I pertemuan 1 siswa memperoleh skor nilai 8 dengan kriteria kurang baik sedangkan siklus I pertemuan 2 memperoleh skor nilai 9 dengan kriteria kurang baik. Penelitian ini yang dilakukan selama 1 siklus yang terdiri dari 2 pertemuan berhasil mencapai indikator keberhasilan dengan kemampuan berpikir kreatif siswa mencapai kriteria baik dan belum mencapai indicator keberhasilan dengan kemampuan sikap rasa ingin tahu mencapai kriteria baik.

Model pembelajaran STM, memberikan dampak yang baik pada kegiatan proses pembelajaran, hal ini dibuktikan siswa mampu meningkatkan kemampuan berpikir kreatifnya dalam memecahkan suatu masalah melalui tahapan pada pembelajaran sesuai dengan tahapan model pembelajaran STM. Pada tahap pengembangan konsep, aplikasi konsep dan pemantapan konsep siswa dituntut untuk melatih kepekaan siswa terhadap lingkungan sebagai akibat perkembangan sains dan teknologi, berpartisipasi lebih aktif baik untuk memberikan gagasan, analisis, mencari sumber informasi yang dibutuhkan, mengalisis, membuat kesimpulan. Pada penelitian ini mencapai indikator keberhasilan dengan mencapai skor ratarata 2,08 dengan kriteria baik. Model Sejalan dengan hal ini, menurut Poedjiadi (2010: 124) model pembelajaran STM dapat mengembangkan kemampuan kognitif, afektif dan psikomotor yang secara utuh dibentuk dalam diri individu sebagai siswa dengan dengan harapan agar diaplikasikan dalam kehidupan sehari-hari. Melalui model ini diharapkan siswa dapat menghubungkan pengetahuan mereka dengan teknologi yang ada di sekitarnya serta dapat menyelesaikan masalah yang terjadi di lingkungan.

Peningkatan kemampuan berpikir kreatif dan sikap rasa ingin tahu pada siswa kelas IV SD Negeri Pesanggrahan 02, diperoleh hasil rata-rata kemampuan berpikir kreatif siswa dari siklus I dan siklus I pertemuan 2 mengalami peningkatan yaitu siklus I pertemuan 1 sebesar 1,86 dengan krtieria kurang baik, meningkat pada siklus I pertemuan 2 menjadi 2,30 termasuk dalam golongan kriteria baik. Hasil nilai persentase observasi sikap rasa ingin tahu pada siswa dari siklus I pertemuan 1 dan siklus I pertemuan 2 mengalami peningkatan yaitu siklus I pertemuan 1 sebesar 51,14\% dengan kriteria cukup baik, meningkat pada siklus I pertemuan 2 menjadi 68,18\% termasuk dalam golongan kriteria baik. Hal ini dikarenakan penggunaan model pembelajaran STM yang menunjang proses pembelajaran. Kemampuan bepikir kreatif mempunyai peranan penting bagi siswa yang harus dikembangkan supaya siswa lebih mudah memahami konsep dan memiliki sudut pandang yang berbeda dalam mengatasi permasalahan.

\section{KESIMPULAN}

Berdasarkan hasil penelitian yang telah dilakukan selama 1 siklus dalam meningkatkan kemampuan berpikir kreatif dan rasa ingin tahu pada siswa menggunakan model pembelajaran STM (Sains Teknologi Masyarakat) di kelas IV SD Negeri Pesanggrahan 02 menunjukan hasil sesuai dengan indikator keberhasilan yaitu $70 \%$ siswa yang memenuhi kemampuan berpikir kreatif mencapai kriteria baik yaitu $0,6<\mathrm{M} \leq 1,2$, sedangkan hasil rasa ingin tahu pada siswa belum sesuai dengan indikator kerhasilan yaitu kurang dari $70 \%$ siswa yang memenuhi sikap rasa ingin tahu. Peningkatan tersebut terlihat dari hasil rekapitulasi tes kemampuan berpikir 
kreatif yang dikerjakan oleh siswa, hasil observasi sikap rasa ingin tahu, hasil rekapitulasi angket rasa ingin tahu pada siswa, aktivitas kegiatan guru dalam menyampaikan materi pembelajaran dan aktivitas siswa dalam memahami materi pembelajaran. Siklus I pertemuan 1 kemampuan berpikir kreatif dan rasa ingin tahu pada siswa belum mencapai indikator kemampuan berpikir kreatif disebabkan siswa belum mengerti proses pembelajaran menggunakan model STM, siswa hanya fokus terhadap pembuatan proyek dalam proses pembelajaran sehingga siswa kebanyakan memperoleh materi dari proses pembuatan proyek. Pada siklus I pertemuan 2, pembelajaran menggunakan model STM dapat mencapai indikator keberhasilan kemampuan berpikir kreatif dan meningkatnya rasa ingin tahu pada siswa. Keaktifan guru saat kegiatan belajar sangat mempengaruhi hasil tes, pada saat pembelajaran dimulai siswa antusias serta semangat di proses pembelajaran melalui model pembelajaran STM lebih menyenangkan dan bermakna, sehingga rasa ingin tahu siswa meningkat. Hal ini ditunjukan dengan hasil kemampuan berpikir kreatif yang diperoleh menunjukan peningkatan yaitu siklus I pertemuan 1 memperoleh skor rata-rata 2,18 berkriteria baik, sedangkan siklus I pertemuan 2 skor rata-rata 2,64 dengan kriteria sangat baik. Pada siklus I pertemuan 2, pembelajaran menggunakan model STM masih belum dapat mencapai indikator keberhasilan sikap rasa ingin tahu pada siswa. Hal ini ditunjukan dengan hasil observasi sikap rasa ingin tahu pada siswa yang diperoleh menunjukan peningkatan yaitu siklus I pertemuan 1 memperoleh $51,14 \%$ berkriteria cukup baik, sedangkan siklus I pertemuan 2 memperoleh $68,18 \%$ dengan kriteria baik.

\section{DAFTAR RUJUKAN}

Aly, A., \& R, Eny. (2010). Ilmu Alamiah Dasar. Jakarta: Bumi Aksara.

Arifin, Z. (2013). Evaluasi Pemsbelajaran. Bandung: Remaja Rosdakarya.

Arikunto, S., dan C. S. A. Jabar. (2009). Evaluasi Program Pendidikan. Jakarta: Bumi Aksara.

Arikunto, S. (2010). Dasar-dasar Evaluasi Pendidikan. Jakarta: Bumi Aksara.

Arini, W., \& A. Asmila. (2017). Analisis Kemampuan Berpikir Kreatif pada Materi Cahaya Siswa Kelas VIII SMP XA Verius Kota Lubuklinggau. Science and Physics Education Jounal, 1 (1): 23-28.

Asmoro, B.P., \& F.D. Mukti. (2019). Peningkatan Rasa Ingin Tahu Ilmu Pengetahuan Alam Melalui Model Contextual Teaching And Learning Pada Siswa Kelas V A Sekolah Dasar Negeri Karangroto 02. Jurnal Abdau, 2(1): 120121.

Djamarah, S. B. (2010). Guru dan Anak Didik dalam Interaksi Edukatif. Jakarta: Rineka Cipta.

Hacieminoglu, E., dkk. (2015). Differences between Students in STS and Non-STS Classrooms Regarding Creativity. Revista de Cercetare si Interventie Sociala, 50.

Hendrayana, S. (2017). Meningkatkan Keterampilan Berpikir Rasional Siswa Melalui Model Sains Teknologi Masyarakat pada Konsep Sumber Daya Alam. Pendas: Jurnal Ilmiah Pendidikan Dasar, 2(1), 73-98.

Hunaepi, dkk. (2014). Sains Teknologi Masyarakat Strategi, Pendekatan, dan Model Pembelajaran. Lombok: Duta Pustaka Ilmu.

Kurniawan, D. (2014). Pembelajaran Terpadu Tematik. Bandung: Alfabeta.

Kusumah, W., \& D. Dwitagama. (2010). Mengenal Penelitian Tindakan Kelas. Jakarta: Indeks.

Maskanah, S., \& A. G. C. Wicaksono. (2019). Pengaruh Model Pembelajaran Debate Terhadap Berpikir Kreatif Siswa SMA Negeri 11 Semarang Melalui LSLC. Edusaintek, 3.

Nurlaela,L., \& E. Ismayanti. (2015). Strategi 
Belajar Berfikir Kreatif. Yogyakarta: Ombak.

Pluck, G., \& H. Johnson. (2011). Stimulating Curiosity to Enchance Learning. Education Science and Psychology, 2(19): 24-29.

Poedjiadi, A. (2010). Sains Teknologi Masyarakat Model Pembelajaran Kontekstual Bermuatan Nilai. Bandung: Remaja Rosdakarya.

Purwanto, N. (2017). Prinsip-prinsip dan Teknik Evaluasi Pengajaran. Bandung: Remaja Rosdakarya.

Pratomo, S., T. Sumiati., \& R. Mursilah. Penerapan Model Sains Teknologi Masyarakat (STM) Untuk Meningkatkan Keterampilan Berpikir Kreatif Siswa Kelas V Di Sekolah Dasar. Metodik Didaktik, 13(1).

Utami, S. H. A., M. Mawardi., \& S. Astuti. (2019). Improving Critical Thingking Skills And Learning Outcomes Using Science Technology Socesty (STS) Learning Model On The $5^{\text {th }}$ Grade Elementary School Students. JPsd (Jurnal Pendidikan Sekolah Dasar), 5(1), 137-149.

Samani, M. dan Hariyanto. (2012). Konsep dan Model Pendidikan Karakter. Bandung: Remaja Rosdakarya.

Santi, D. K. (2014). Peningkatan Keterampilan Proses dan Hasil Belajar IPA Menggunakan Model Pembelajaran Sains Teknologi Masyarakat (STM) pada Siswa Kelas VI SDN 1 Kalinanas-Wonosegoro. Scholaria: Jurnal Pendidikan Dan Kebudayaan, 4(3), 122-131.

Septiawan, I. G. K., Ni, W. Arini., \& I, G. W. Sudatha. (2014). Penerapan Model Pembelajaran Sains Teknologi Masyarakat (STM) Berbantuan Media Audio Visual Untuk Meningkatkan Hasil Belajar IPA pada Siswa Kelas V Semester Ganjil di SD Negeri 2 Sudaji, Kecamatan Sawan, Kabupaten Buleleng Tahun Pelajaran 2013/2014. MIMBAR PGSD Undiksha, 2(1).

Sudijono, A. (2012). Pengantar Evaluasi Pendidikan. Jakarta: PT Raja Grafindo
Persada.

Sudjana, N. (2011). Penilaian Hasil Proses Belajar Mengajar. Bandung: Remaja Rosda Karya.

Sutarna, N. (2018). Pendidikan Karakter Siswa Sekolah Dasar. Yogyakarta: Pustaka Diniyah.

Tim Pusat Penilaian Pendidikan. (2019). Panduan Penilaian Tertulis. Jakarta: Pusat Penilaian Pendidikan.

Widoyoko, E.P. (2018). Teknik Penyusunan Instrumen Penelitian. Yogyakarta: Pustaka Pelajar.

Winarsih, A., and S. Mulyani. (2012). Peningkatan profesionalisme guru IPA melalui lesson study dalam pengembangan model pembelajaran $\mathrm{PBI}$. Jurnal Pendidikan IPA Indonesia. 1.1. 